\title{
PENERAPAN MODEL LEVELS OF INQUIRY UNTUK MENINGKATKAN PENGUASAAN KONSEP SISWA PADA MATERI TATA SURYA SMP
}

\author{
Annisa Nurjanah ${ }^{1 *}$, Taufik Ramlan Ramalis ${ }^{1}$, Dadi Rusdiana ${ }^{1}$ \\ ${ }^{1}$ Departemen Pendidikan Fisika, FPMIPA, Universitas Pendidikan Indonesia \\ *Email: nurjanah99@student.upi.edu
}

\begin{abstract}
Abstrak: Penelitian ini bertujuan untuk mengetahui peningkatan penguasaan konsep Tata Surya setelah penerapan model Levels of Inquiry. Metode penelitian yang dilakukan adalah quasy experiment dengan one group pretest-posttest design yang dilaksanakan di salah satu SMP di Lembang, Jawa Barat. Instrumen penguasaan konsep menggunakan soal tes uraian yang terdiri dari aspek kognitif memahami (C2), menerapkan (C3), dan menganalisis (C4) yang saling berkesinambungan pada setiap butir soal. Berdasarkan analisis data uji hipotesis disimpulkan bahwa penerapan model Levels of Inquiry dapat meningkatkan penguasaan konsep pada materi Tata Surya dengan skor $N$-gain 0.48 yakni dalam kategori sedang.
\end{abstract}

Kata Kunci: Levels Of Inquiry, Quasy Experiment, Penguasaan Konsep,

\section{PENDAHULUAN}

Levels of Inquiry merupakan tahapan pembelajaran yang melatihkan kemampuan siswa dalam hal berpikir kritis dan berpikir struktural untuk bisa memahami suatu konsep. Hirarki inkuiri ini bergeser dari guru ke siswa atau bergerak dari kiri ke kanan, seperti diperlihatkan pada Tabel 1.

Tabel 1. Hirarki Proses Inkuiri dari Wenning (2005)

\begin{tabular}{lllll}
\hline $\begin{array}{l}\text { Discovery } \\
\text { Learning }\end{array}$ & $\begin{array}{l}\text { Interactive } \\
\text { Demonstration }\end{array}$ & $\begin{array}{l}\text { Inquiry } \\
\text { Lesson }\end{array}$ & $\begin{array}{l}\text { Inquiry Laboratory } \\
\text { Application }\end{array}$ & $\begin{array}{l}\text { Hypoth } \\
\text { etical } \\
\text { Inquiry }\end{array}$ \\
\hline Low & Intellectual Sophistication & High \\
Teacher & Locus of Control & Student \\
\hline
\end{tabular}

Pada bagian Discovery learning guru berperan dominan, sedangkan pada Hypothetical inquiry pekerjaannya sangat tergantung pada siswa. Pengalaman intelektual meningkat juga dari Discovery learning melalui Hypothetical inquiry. 
Pemikiran diperlukan untuk mengendalikan suatu kegiatan yang bergeser dari guru ke siswa sebagai praktik kemajuan sepanjang sisi kanan secara kontinu.

Penguasaan konsep merupakan salah satu hasil belajar dalam dimensi proses kognitif. Kemampuan dalam dimensi kognitif dikategorikan menjadi enam tahapan menurut Bloom, yakni $\mathrm{C} 1$ (mengingat), $\mathrm{C} 2$ (memahami), $\mathrm{C} 3$ (mengaplikasikan), C4 (menganalisis), C5 (mengevaluasi), dan C6 (menciptakan). Materi yang menjadi bahan penelitian ini adalah tata surya yang sering disampaikan secara informatif, dan berdasarkan hasil wawancara di SMP di Jawa Barat bahwa materi ini sering ditiadakan atau diberikan dalam waktu yang singkat karena yang disampaikan masih mirip dengan materi yang sudah diajarkan di SD. Padahal materi Tata surya adalah materi fisika yang menarik bagi siswa karena berbeda konteks pembicaraannya yang mengenai dunia antariksa untuk membuka wawasan siswa lebih luas.

Pada penelitian ini akan dilatihkan kepada siswa dalam aspek kognitif lainnya yakni memahami (C2), menerapkan (C3), dan menganalisis (C4).

Tabel 2. Hubungan Levels of Inquiry dan Penguasaan Konsep

\begin{tabular}{ll}
\hline \multicolumn{1}{c}{ Levels of Inquiry } & \multicolumn{1}{c}{ Penguasaan Konsep } \\
\hline Discovery learning & mengingat $(\mathrm{C} 1)$, memahami $(\mathrm{C} 2)$ \\
Interactive demonstration & memahami $(\mathrm{C} 2)$, menerapkan $(\mathrm{C} 3)$ \\
Inquiry lesson & $\begin{array}{l}\text { memahami }(\mathrm{C} 2), \text { menerapkan }(\mathrm{C} 3), \\
\text { menganalisis }(\mathrm{C} 4)\end{array}$ \\
Inquiry lab & $\begin{array}{l}\text { memahami }(\mathrm{C} 2), \text { menerapkan }(\mathrm{C} 3), \\
\text { menganalisis }(\mathrm{C} 4)\end{array}$ \\
\hline
\end{tabular}

\section{METODE}

Desain penelitian yang digunakan adalah Quasy Experiment dengan one group pretest-posttest design, responden diambil dengan cara purposive sampling yakni hanya dipilih satu kelas di salah satu SMP di Lembang dengan jumlah responden tetap yang dijadikan sampel adalah 30 orang siswa. Analisis yang dilakukan adalah melihat perkembangan siswa di satu kelas tersebut selama 3 pertemuan untuk materi Tata surya yakni untuk sub materi zona waktu, fase bulan, dan gerhana matahari. Setiap pertemuan siswa diberikan eksperimen yang didesain berbeda dan pembelajaran menggunakan model Levels of Inquiry, 
kemudian untuk melihat peningkatan penguasaan konsep siswa yakni dibandingkan antara hasil pretest dan posttest yang dilakukan siswa

Instrumen yang digunakan untuk mengukur keterlaksanaan model pembelajaran Levels of Inquiry berupa lembar penilaian oleh observer setiap tahapan yang diterapkan (Discovery learning, Interactive demonstration, Inquiry lesson, dan Inquiry laboratory). Penilaian yang dilakukan menggunakan skala skor 0-100. Sedangkan untuk mengetahui peningkatan penguasaan konsep pada siswa maka dengan menggunakan instrumen tes berupa pretest dan posttest dengan soal yang sama, penilaian dilakukan dengan membuat rubrik holistik yang dikembangkan dari Mertler (2012) dengan skor 0-4 kemudian dikonversi ke dalam skala 0-100.

Teknik pengumpulan data yang dilakukan, pertama dengan melakukan uji coba instrumen, kemudian diuji validitas, menggunakan validitas logis oleh dua orang dosen dan satu orang guru SMP dan dihitung menggunakan CVR (Content Validity Ratio) dan CVI (Content Validity Index), uji reliabilitas menggunakan Cronbach Alpha karena instrumen tes dalam bentuk uraian, tingkat kesukaran, dan daya pembeda. Peningkatan penguasaan konsep dengan uji hipotesis menggunakan uji t pihak kanan.

\section{HASIL DAN PEMBAHASAN}

Berdasarkan hasil penilaian dari observer bahwa di setiap tahapan, guru masih lebih mendominasi dibandingkan siswa. Perbandingan guru dan siswa pada tahap Discovery learning yakni 93\% dan 88\%, tahap Interactive demonstration yakni $84 \%$ dan $78 \%$, tahap Inquiry lesson yakni $81 \%$ dan $78 \%$, dan tahap Inquiry laboratory yakni $85 \%$ dan $81 \%$. Rerata keseluruhan juga menunjukkan bahwa keterlaksanaan oleh guru lebih besar dari pada siswa dengan hasil keterlaksanaan guru adalah $86 \%$ dan siswa adalah $81 \%$.

Khususnya pada pertemuan pertama bahwa keterlaksanaan Levels of Inquiry oleh siswa tidak berjalan dengan baik karena siswa baru mendapatkan cara belajar menggunakan model seperti ini, sehingga berpengaruh terhadap keaktifan siswa di dalam kelas sehingga untuk membuat siswa paham maka dominasi guru yang sangat tinggi untuk menjelaskan maksud dan tujuan di setiap tahapan dan juga membutuhkan waktu ekstra pada tahapan Interactive demonstration dan Inquiry lesson ketika mengenalkan variabel kepada siswa, karena siswa belum memahami apa yang dimaksud dengan variabel bebas, variabel terikat, dan variabel kontrol. 
Namun terdapat peningkatan keterlaksanaan untuk setiap pertemuan berikutnya, hal ini terjadi karena siswa mulai memahami cara penyampaian yang sesuai dan siswa tertarik untuk belajar dengan pendekatan bereksperimen, percobaan, video animasi, dan pengantar-pengantar lainnya supaya siswa terlibat secara langsung untuk bisa memahami konsep.

Hasil uji normalitas sebagai syarat melakukan uji hipotesis yakni menggunakan metode Liliefors yang menghasilkan nilai $\mathrm{L}_{\text {hit }}<\mathrm{L}_{\text {tabel }}$ untuk masing-masing data pretest dan posttest yang berarti bahwa kedua data tersebut terdistribusi normal. Berikut adalah hasil uji t pihak kanan,

Tabel 3. Hasil Uji t untuk Setiap Aspek Kognitif

\begin{tabular}{ccccccc}
\hline Hasil & \multicolumn{3}{c}{ Pretest } & \multicolumn{3}{c}{ Posttest } \\
& $\mathrm{C} 2$ & $\mathrm{C} 3$ & $\mathrm{C} 4$ & $\mathrm{C} 2$ & $\mathrm{C} 3$ & $\mathrm{C} 4$ \\
\hline Rerata & 40.4 & 31.7 & 16.3 & 68.8 & 71.3 & 50.8 \\
$\mathrm{SD}$ & 21.8 & 15.6 & 10.4 & 9.8 & 10.9 & 9.5 \\
$\mathrm{R}$ & 0.5005 & 0.4666 & 0.3633 & Nilai maksimal 100 \\
$\alpha$ & \multicolumn{5}{c}{0.05} \\
$\mathrm{t}_{\text {hit }}$ & -8.196 & -15.18 & -16.77 & & \\
$\mathrm{t}_{\text {tabel }}$ & \multicolumn{5}{c}{1.703} \\
$\mathrm{t}_{\text {hit }}<\mathrm{t}_{\text {tabel }}$ & \multicolumn{3}{c}{ untuk setiap aspek } \\
\multicolumn{5}{c}{ kognitif } \\
\hline
\end{tabular}

Hasil uji $\mathrm{t}$ secara keseluruhan juga menunjukkan nilai $\mathrm{t}_{\text {hit }}<\mathrm{t}_{\text {tabel }}\left(\mathrm{t}_{\text {hit }}=\right.$ 15.435 dan $t_{\text {tabel }}=1.703$ ) yang menjelaskan bahwa hasil pretest siswa sebelum model Levels of Inquiry lebih kecil atau sama dengan setelah diterapkan Levels of Inquiry. Sedangkan analisis menggunakan normalized gain untuk aspek memahami (C2) dengan skor 0.48, aspek menerapkan (C3) dengan skor 0.58, aspek menganalisis (C4) dengan skor 0.41, dan secara keseluruhan didapatkan skor 0.48. Terdapat peningkatan penguasaan konsep untuk setiap aspek maupun secara keseluruhan dalam kategori sedang/ cukup.

Hasil yang tidak terlalu signifikan ini dikarenakan kemampuan siswa dalam penguasaan konsep yang masih terbilang minim untuk kategori soal-soal memahami, menerapkan, dan menganalisis. Menurut Piaget dalam Slavin (2009: 
52) bahwa anak usia di atas 11 tahun sudah bisa berpikir formal yang berarti sudah bisa berpikir abstrak. Namun berdasarkan beberapa penelitian Nurhidayati (2017) pada salah satu SMA di Pontianak bahwa kemampuan berpikir formal/ abstrak hanya mencapai $10,71 \%$ yang berarti masih sangat rendah dan menurut Erman dalam Nurhidayati (2017) siswa SMU pada umumnya masih berkemampuan berpikir konkrit. Sedangkan pada materi Tata surya yang diberikan pada siswa SMP diminta untuk berpikir abstrak.

\section{KESIMPULAN}

Berdasarkan pengolahan data keterlaksanaan model Levels of Inquiry, uji t pihak kanan, dan normalized gain bahwa penerapan model Levels of Inquiry dapat meningkatkan penguasaan konsep siswa pada materi Tata surya SMP.

\section{REFERENSI}

Anderson, L., \& Krathwohl, D. (2010). Kerangka Landasan untuk Pembelajaran, Pengajaran, dan Asesmen: Revisi Taksonomi Bloom. Yogyakarta: Pustaka Pelajar.

Arikunto, S. (2012). Dasar-Dasar Evaluasi Pendidikan. Jakarta: Bumi Aksara

Asra, A. Irawan, P. B., \& Purwoto, A. (2016). Metode Penelitian Survey. Jakarta: In Media.

Chandra, M. (2014). Pengunaan Website dalam Model Perubahan Konseptual Dengan Setting Kooperatif Problem Solving untuk Meningkatkan Pemahaman Konsep dan Kemampuan Pemecahan Masalah Siswa SMA pada Materi Teori Kinetik Gas. Tesis. Bandung: Program Studi Pendidikan Fisika Sekolah Pascasarjana. Universitas Pendidikan Indonesia.

Danika, Inka. (2018). Penerapan Levels of Inquiry (LoI) untuk Mengidentifikasi Perkembangan Kemampuan Bereksperimen dan Meningkatkan Penguasaan Konsep Energi Di SMP. Skripsi. Bandung: Universitas Pendidikan Indonesia.

Departemen Pendidikan Nasional. (2013). Kurikulum 2013 Standar Kompetensi Mata Pelajaran Sains Sekolah Menengah Pertama dan Madrasah Tsanawiyah Departemen Pendidikan Nasional. Jakarta

Furqon. (2014). Statistik Terapan untuk Penelitian. Bandung: Alfabeta

Hake, Richard R. (1998). Interactive-Engagement versus Traditional Methods: A Six-Thousand-Student Survey of Mechanis Test Data for Introductory Physics Courses. American Journal of Physics, 66(64)

Ihda, Citra. (2013). Levels of Inquiry Model dan Kemampuan Inkuiri. Bandung: UPI

Kaniawati, Ida. 2015. Skala Pengukuran dan Instrumen Penelitian (Ms. Power Point). Bandung: UPI.

Lati, Wichai. dkk. (2012). Enhancement of Learning Achievement and Integrated Science Process Skills Using Science Inquiry Learning Activities of 
Chemical Reaction Rates. Journal in Procedia- Social and Behavioral Sciences, 46, 4471-4475

Mertler, Craig A. (2001). Designing Scoring Rubrics for Your Classroom. A peerreviewed electronics journal, 7(25), 1-8

Nurhidayati, dkk. (2017). Deskripsi Kemampuan Berpikir Formal Siswa pada Materi Kimia Kelas XI SMA Negeri 2 Pontianak. Diakses dari: http://repository.unmuhpnk.ac.id/329/

Robert E. Slavin. (2000). Educational Psychology: Theory and Practice. Pearson Education. New Jersey.

Sugiyono. (2010). Statistika untuk Penelitian. Bandung: Alfabeta

Sujarweni, V. W., \& Endrayanto, P. (2011). Statistika untuk Penelitian. Yogyakarta: Graha Ilmu.

Tipler, Paul A. (1998). Fisika untuk Sains dan Terbaik. Jakarta: Erlangga

Utari, Setiya. (2010). Pengembangan Program Perkuliahan Untuk Membekali Calon Guru Dalam Merencanakan Kegiatan Eksperimen Fisika di Sekolah Menengah. Disertasi. UPI Bandung: tidak diterbitkan.

Wenning, C. J. (2005). Levels of Inquiry: Hierarchies of Pedagogical Practices

and Inquiry Processes (revised 2/12). Illinois State Univesity 